\title{
Turbulence Promoters for Heat Transfer Enhancement
}

\author{
Jorge C Melo Gonzalez and Martin Picon Nunez* \\ Department of Chemical Engineering, University of Guanajuato, Mexico \\ *Corresponding author: Martin Picon Nunez, Department of Chemical Engineering, University of Guanajuato, Mexico.
}

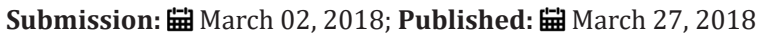

\begin{abstract}
Heat transfer enhancement technologies have witnessed a rapid growth in recent years. Passive process intensification methods are a very effective tool to reduce the size of heat exchanger equipment or to enhance the capacity of existing units. This is achieved by means of turbulence promoters of different geometries. This turbulence promoter affects the heat transfer process and the pressure drop. In this paper, turbulence promoters used under turbulent regime are analyzed based on the thermal improvement factor $(\eta)$. This factor gives an indication of the improvement in heat transfer and pressure drop and provides the means for a reliable performance comparison and selection.
\end{abstract}

\section{Introduction}

The concern about increasing energy recovery maintaining low capital investment had oriented research to the development of new ways of process intensification techniques. Heat exchangers are important pieces of equipment in areas such as air conditioning, cooling and, heating systems, car radiators, chemical reactors cooling or heating, solar collectors, etc. Therefore, the search for new heat transfer surface of the system and more efficient ways of enhancing heat transfer is major technological trend seeking to achieve the same heat duty in a smaller unit subject to the limitations imposed by pressure drop.

Heat transfer enhancement techniques improve the heat transfer coefficient which brings about a reduction in the heat transfer area or the increase of the heat transfer capacity. Heat transfer enhancement techniques are classified in two main groups: active and passive. Active methods require external power, for instance, fluid suction or injection, electrostatic fields, surface fluid vibrations, etc. Passive methods consist in the modification of the heat transfer surface of the system. Examples of these are the heat transfer inserts that generate turbulence and produce eddies and vortices. The main feature of such devices is that they reduce the laminar boundary layer next to the walls which is the major resistance to heat transfer inside a tube. This technology is considered a key heat transfer enhancement due to their high performance, low cost, ease of construction, simple installation and removal for cleaning. They can be made on almost any material of construction such as aluminum, copper, carbon steel and stainless steel, among others.
Over the last decade, a lot of work has been done over the development and performance of turbulent promoters. Since most industrial heat exchangers operate under a turbulent regime, this has been the focus of the research. The main types of turbulent promoters are the twisted tapes [1-5], winglets tapes [6,7] circular rings [3,8], baffles [9], helical inserts [10] and coil-wires [11]. Research has been focused on these geometries seeking to optimize their design. For instance, Bhuiya et al. [1] studied a modified twisted tape which included different size perforations along the tape. Murugusen et al. [2] reported the heat transfer features of twisted tape with pins. Eiamsa et al. [3] investigated experimentally the effect on heat transfer of a tube fitted with circular-rings combined with twisted tapes. The performance of a twisted tape with V-cuts in different sizes was reported by Murugusen et al. [4]. Wongcharee and Eiamsa-ard [5] investigated different modifications on twisted tape fins obtaining significant improvement on all new geometries. Skullong et al. [6] studied the modification of a delta-winglet tape obtaining an increase of five times the heat transfer rate. Skullong et al. [7] reported the heat transfer augmentation and the friction factor of a winglet perforated t-tape obtaining improved results. Chingtuaythong et al. [8] show the effect of V-shaped rings through a pipe with different diameters obtaining a considerable heat transfer increase but a considerable increase on the friction factor. Promvonge et al. [9] carried out and experimental study of inclined horseshoes baffles with different inclination angles. Bhuiya et al. [10] realized studies on a triple helical tape insert finding very promising enhancement performance. All these experiments were carried out under turbulent Flow with water and air. 


\begin{tabular}{|c|c|c|c|}
\hline \multicolumn{4}{|c|}{ Nomenclature } \\
\hline $\mathrm{f}$ & Friction factor & & \\
\hline hp & $\begin{array}{l}\text { thermal convective heat transfer } \\
\text { coefficient for inserts }[\mathrm{W} /(\mathrm{mK})]\end{array}$ & $\Delta \mathrm{P}$ & $\begin{array}{l}\text { pressure drop along the length of } \\
\text { the tube }\left[\mathrm{N} / \mathrm{m}^{2}\right]\end{array}$ \\
\hline hs & $\begin{array}{l}\text { thermal convective heat transfer } \\
\text { coefficient for plain tube, }[\mathrm{W} /(\mathrm{mK})]\end{array}$ & $\eta$ & thermal enhancement factor, TEF \\
\hline $\operatorname{Re}$ & Reynolds number & Subscripts & \\
\hline $\mathrm{Re}_{\mathrm{p}}$ & $\begin{array}{c}\text { Reynolds number for the tube with } \\
\text { inserts }\end{array}$ & & \\
\hline $\mathrm{Re}_{s}$ & Reynolds number for the plain tube & $\mathrm{p}$ & promoter \\
\hline & & $\mathrm{s}$ & plain \\
\hline $\mathrm{V}$ & Mass Velocity [Kg/s] & $\mathrm{pp}$ & pumpingpower \\
\hline
\end{tabular}

Table 1a \& b shows a selection of the main geometries of turbulence promoters developed. These are those that exhibit high thermal performance and low pressure drop. The heat transfer improvement of these promoters goes from $30-500 \%$. The values

of the coefficient of thermal improvement are between $30-370 \%$ larger than unity, which makes them suitable for industrial applications.

Table1a \& b: Features of relevant turbulence promoters reported in the literature.

\begin{tabular}{|c|c|c|c|c|c|c|c|c|}
\hline $\begin{array}{l}\text { Turbulence Promoter } \\
\text { Configuration }\end{array}$ & Reference & Name & $\begin{array}{l}\text { Working } \\
\text { Fluid }\end{array}$ & Parameters & $\begin{array}{l}\text { Reynolds } \\
\text { Range }\end{array}$ & Nup/Nus & $\mathrm{fp} / \mathrm{fs}$ & 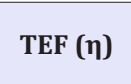 \\
\hline$=\frac{0<}{10}$ & $\begin{array}{l}\text { MMK } \\
\text { Bhuiya } \\
\text { et al. [1] }\end{array}$ & $\begin{array}{l}\text { Perforated } \\
\text { twisted tape }\end{array}$ & $\begin{array}{l}\text { Air, } \\
\text { turbulent }\end{array}$ & $\mathrm{Rp}=1.6-14.7 \%$ & $7,200-49,800$ & $2.07-4-4$ & $2.1-4.6$ & $1.28-1.59$ \\
\hline & \multirow{4}{*}{$\begin{array}{l}\text { Murugusen } \\
\text { et al. [2] }\end{array}$} & \multirow{4}{*}{$\begin{array}{l}\text { Twisted tape } \\
\text { with wire- } \\
\text { nails }\end{array}$} & \multirow{4}{*}{$\begin{array}{l}\text { Air, } \\
\text { turbulent }\end{array}$} & $y=2,4.4,6$ & \multirow{4}{*}{$2,000-12,000$} & \multirow{4}{*}{$1.66-1.93$} & \multirow{4}{*}{$2.67-5.8$} & \multirow{4}{*}{$1.06-1.30$} \\
\hline & & & & $\mathrm{Lw}=14 \mathrm{~mm}$ & & & & \\
\hline & & & & $\mathrm{dw}=2 \mathrm{~mm}$ & & & & \\
\hline & & & & $\mathrm{dh}=4 \mathrm{~mm}$ & & & & \\
\hline & \multirow[b]{2}{*}{$\begin{array}{l}\text { Eiamsaard } \\
\text { et al. [3] }\end{array}$} & \multirow[b]{2}{*}{$\begin{array}{l}\text { Circular-rings } \\
\text { and twisted } \\
\text { tapes }\end{array}$} & \multirow[b]{2}{*}{$\begin{array}{l}\text { Air, } \\
\text { turbulent }\end{array}$} & $\mathrm{y} / \mathrm{W}=3,4,5$ & \multirow[b]{2}{*}{$6,000-20,000$} & $\begin{array}{c}\text { CR alone } \\
2.36-2.80\end{array}$ & $\begin{array}{c}\text { CR alone } \\
7.4-13.75\end{array}$ & $\begin{array}{l}\text { CR alone } \\
1.09-1.25\end{array}$ \\
\hline & & & & $\mathrm{l} / \mathrm{Di}=1,1.5,2$ & & $\begin{array}{l}\text { CR and TT } \\
2.44-4.70\end{array}$ & $\begin{array}{l}\text { CR and } \\
\text { TT } 11.94- \\
35.83\end{array}$ & $\begin{array}{l}\text { CR and TT } \\
1.04-1.42\end{array}$ \\
\hline \multirow[t]{2}{*}{ 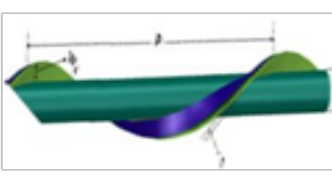 } & \multirow[t]{2}{*}{$\begin{array}{c}\text { MMK } \\
\text { Bhuiya } \\
\text { et al. [10] }\end{array}$} & \multirow[t]{2}{*}{$\begin{array}{l}\text { Triple helical } \\
\text { tape insert }\end{array}$} & \multirow[t]{2}{*}{$\begin{array}{c}\text { Air, } \\
\text { turbulent }\end{array}$} & $\alpha=9,13,17,21^{\circ}$ & \multirow[t]{2}{*}{$\begin{array}{l}22,000- \\
51,000\end{array}$} & \multirow[t]{2}{*}{$2.75-4.50$} & \multirow[t]{2}{*}{$1.9-3.0$} & \multirow[t]{2}{*}{$2.15-3.70$} \\
\hline & & & & $\operatorname{rod}=12 \mathrm{~mm}$ & & & & \\
\hline \multirow{3}{*}{ 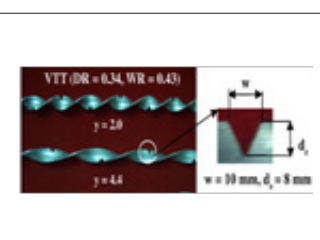 } & \multirow{3}{*}{$\begin{array}{l}\mathrm{P} \\
\text { Murugusen } \\
\text { et al. [4] }\end{array}$} & \multirow{3}{*}{$\begin{array}{l}\text { V-Cuttwisted } \\
\text { tape }\end{array}$} & \multirow{3}{*}{$\begin{array}{l}\text { Water, } \\
\text { turbulent }\end{array}$} & $y=2,4.4,6$ & \multirow{3}{*}{$2,000-20,000$} & \multirow{3}{*}{$1.36-2.46$} & \multirow{3}{*}{$2.49-5.82$} & \multirow{3}{*}{$1.07-1.27$} \\
\hline & & & & $\begin{array}{c}\mathrm{de} / \mathrm{W}=0.34 \\
0.43\end{array}$ & & & & \\
\hline & & & & $\begin{array}{l}\mathrm{w} / \mathrm{W}=0.34 \\
0.43\end{array}$ & & & & \\
\hline \multirow{4}{*}{ 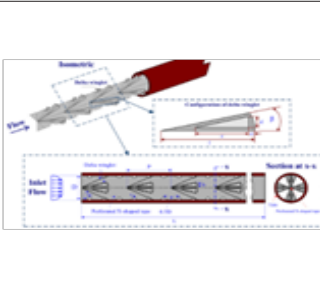 } & \multirow{4}{*}{$\begin{array}{l}\text { Sompol } \\
\text { Skullong et } \\
\text { al. [6] }\end{array}$} & \multirow{4}{*}{$\begin{array}{c}\text { Quadruple } \\
\text { perforated- } \\
\text { delta-winglet } \\
\text { (PW-XT) } \\
\text { and Typical } \\
\text { winglet } \\
\text { (TW-XT) }\end{array}$} & \multirow{4}{*}{$\begin{array}{l}\text { Air, } \\
\text { turbulent }\end{array}$} & $\begin{array}{c}\mathrm{BR}=0.1,0.15 \\
0.2,0.25\end{array}$ & \multirow{4}{*}{$4,180-26,000$} & PW-XT & PW-XT & $\begin{array}{l}\text { PW-XT } \\
1.42-1.90\end{array}$ \\
\hline & & & & $\begin{array}{c}\mathrm{PR}=0.5,1.0 \\
1.5,2.0\end{array}$ & & $1.96-5.06$ & $\begin{array}{l}2.06- \\
35.68\end{array}$ & $\begin{array}{l}\text { TW-XT } \\
1.46-1.73\end{array}$ \\
\hline & & & & $\alpha=30^{\circ}$ & & TW-XT & TW-XT & \\
\hline & & & & $\beta=5.7,8.6,11.4$, & & $5.14-5.28$ & $\begin{array}{c}28.13- \\
43.72\end{array}$ & \\
\hline
\end{tabular}




\begin{tabular}{|c|c|c|c|c|c|c|c|c|}
\hline $\begin{array}{l}\text { Turbulence } \\
\text { Promoter } \\
\text { Configuration }\end{array}$ & Reference & Name & $\begin{array}{l}\text { Working } \\
\text { Fluid }\end{array}$ & Parameters & $\begin{array}{c}\text { Reynolds } \\
\text { Range }\end{array}$ & Nup/Nus & $\mathrm{fp} / \mathrm{fs}$ & TEF ( $\eta)$ \\
\hline \multirow{3}{*}{ Thatar } & \multirow{3}{*}{$\begin{array}{c}\text { Wongcharee and } \\
\text { Eiamsaard [5] }\end{array}$} & \multirow{3}{*}{$\begin{array}{c}\text { TT with } \\
\text { alternate axes } \\
\text { with different } \\
\text { wings }\end{array}$} & \multirow{3}{*}{$\begin{array}{l}\text { Water, } \\
\text { turbulent }\end{array}$} & $\begin{array}{c}\mathrm{d} / \mathrm{W}=0.1,0.2, \\
0.3\end{array}$ & \multirow{3}{*}{$\begin{array}{l}5,500- \\
20,200\end{array}$} & Tra 1.74-2.85 & Tra 4.35-7.99 & $\begin{array}{c}\text { Tra 1.06- } \\
1.42\end{array}$ \\
\hline & & & & $\mathrm{b} / \mathrm{W}=0.2$ & & Rec $1.68-2.64$ & Rec $3.83-6.72$ & $\begin{array}{c}\text { Rec 1.05- } \\
1.39\end{array}$ \\
\hline & & & & $\mathrm{y} / \mathrm{W}=4.0$ & & Tri 1.62-2.49 & Tri 3.54-6.26 & Tri 1.04-1.35 \\
\hline \multirow{4}{*}{+4} & \multirow{4}{*}{$\begin{array}{l}\text { SompolSku-llong } \\
\text { et al. [7] }\end{array}$} & \multirow{4}{*}{$\begin{array}{c}\text { Staggered- } \\
\text { winglet } \\
\text { perforated- } \\
\text { tapes (WPT) } \\
\text { and Staggered- } \\
\text { winglet tape } \\
\text { (WTT) }\end{array}$} & \multirow{4}{*}{$\begin{array}{l}\text { Air, } \\
\text { turbulent }\end{array}$} & $\begin{array}{c}\mathrm{BR}=0.1,0.15, \\
0.2,0.25,0.3\end{array}$ & \multirow{4}{*}{$\begin{array}{l}4,180- \\
26,000\end{array}$} & $\begin{array}{l}\text { WPT } 2.39- \\
4.78\end{array}$ & WPT & WPT \\
\hline & & & & $\begin{array}{c}\mathrm{PR}=0.5,1.0, \\
1.5\end{array}$ & & & $4.87-42.69$ & $1.23-1.71$ \\
\hline & & & & $\alpha=30^{\circ}$ & & WTT & WTT & WTT \\
\hline & & & & $\mathrm{Ah} / \mathrm{At}=0.125$ & & $4.63-4.90$ & $33.46-49.80$ & $1.26-1.52$ \\
\hline \multirow{3}{*}{$\sqrt{8288}$} & \multirow{3}{*}{$\begin{array}{l}\text { Chingtuaythong } \\
\text { et al. [8] }\end{array}$} & \multirow{3}{*}{ V-Shappedrings } & \multirow{3}{*}{$\begin{array}{l}\text { Air, } \\
\text { turbulent }\end{array}$} & $\begin{array}{c}\mathrm{RB}= \\
=0.1,0.15 \\
0.2\end{array}$ & \multirow{3}{*}{$\begin{array}{l}5,000- \\
25,000\end{array}$} & \multirow{3}{*}{$2.47-5.77$} & \multirow{3}{*}{$6.57-82.01$} & \multirow{3}{*}{$1.15-1.63$} \\
\hline & & & & $\begin{array}{c}\mathrm{Rp}=0.5,1.0 \\
1.5,2.0\end{array}$ & & & & \\
\hline & & & & $\alpha=30^{\circ}$ & & & & \\
\hline \multirow{4}{*}{$\int_{i x \mid 0}^{1}$} & \multirow{4}{*}{$\begin{array}{l}\text { Promvonge et } \\
\text { al. [9] }\end{array}$} & \multirow{4}{*}{$\begin{array}{l}\text { Inclinedhorsh- } \\
\text { oebaffles }\end{array}$} & \multirow{4}{*}{$\begin{array}{c}\text { Air, } \\
\text { turbulent }\end{array}$} & $\begin{array}{c}\mathrm{BR}=0.1,0.15, \\
0.2\end{array}$ & \multirow{4}{*}{$\begin{array}{l}5,300- \\
24,000\end{array}$} & $20^{\circ}$ & $20^{\circ}$ & $20^{\circ}$ \\
\hline & & & & $\begin{array}{c}P R=0.5,1.0 \\
\quad 2.0\end{array}$ & & $1.92-3.08$ & $1.78-6.76$ & $1.34-1.92$ \\
\hline & & & & $\alpha=20^{\circ}, 45^{\circ}$ & & $45^{\circ}$ & $45^{\circ}$ & $45^{\circ}$ \\
\hline & & & & & & $2.56-3.10$ & $3.16-6.84$ & $1.29-1.82$ \\
\hline
\end{tabular}

(b)

\section{Thermo-hydraulic Traits}

The main heat transfer features emerging from the application of turbulence promoters are described below:

i. The reduction of the hydraulic diameter due to blockage that inserts induce an increment in the fluid velocity: this in turn, increases pressure drop resulting in increased heat transfer inside the tube.

ii. As the Eddy flow increases inside the system, higher turbulence is created near the tube Wall bringing about the rupture of the laminar boundary layer. Finsorprotrusions on the inserts increase turbulence.

iii. Eddy Flow promotes the mixing between the fluid in the central region and the one near the wall. This brings about temperatura uniformity inside the tube.

iv. Some promoters contain holes along its length seeking to reduce the impact on pressure drop.

\section{Performance Comparison Methods}

One of the most widely used performance parameters used to measure the improvement of heat transfer is the Thermal Enhancement Factor ( $\eta$ ). The term assumes that the pumping power between the bare tube and the tube with inserts are the same.This is expressed as [12]

$$
(V \cdot \Delta P)_{p}=(V \cdot \Delta P)_{s}
$$

The relationship between the friction factor and the Reynolds number is given by:

$$
\left(f \cdot R \mathrm{e}^{3}\right)_{p}=\left(f \cdot \mathrm{Re}^{3}\right)_{s}
$$

Or

alternatively by

$$
\left(R \mathrm{e}_{s}\right)=\operatorname{Re}_{p}\left(\frac{f_{p}}{f_{s}}\right)^{\frac{1}{3}}(3)
$$

The Thermal Improvement Factor ( $\eta$ ) is defined as the ratio between the heat transfer coefficient, hp, of the tube with the insert and that of the bare tube hs.

$$
\left.\eta=\frac{h}{p}_{h_{s p p}}=\frac{\left(\frac{N u_{p}}{N u_{s}}\right)}{\left(\frac{f p}{f s}\right)^{\frac{1}{3}}} 4\right)
$$

It is important to mention that all turbulence promoters reduce their $\eta$ as Re increases, except for the triple helical tape insert [10] where the factor increases as Re does.

\section{Selection Guide}

The selection of the suitable turbulence promoter is important to bear in mind the following aspects:

i. The values of $\eta$ must be larger than unity. Above this value, more heat can be recovered for the same geometry and pumping power. 
ii. The Reynolds number range where the insert is to be used must be of the same range. Otherwise there is no guarantee that the rate of heat transfer increment is maintained.

iii. Operating pressures must not exceed the limits established by the materials of construction.

iv. It is important to stick to these selection guides in order to maximize the benefit of the application.

\section{Conclusion}

This review focuses of the recent experimental studies of turbulence promoters used in tubular heat exchangers. It is a proven fact that turbulence promoters are effective in enhancing thermo-hydraulic performance, which brings about increased energy recovery at the expense of increased pressure drop. Current performance comparison techniques are adequate to effectively select the right type of insert that for a given application provides the best results. This can be in the way of increased capacity for the same geometry or reduced surface area for the same duty. The inserts reported in this work are those that exhibit a performance factor larger than unity. This feature makes them suitable if they are used within the operating range for which they were tested. The insert that has the largest performance factor is the triple helical tape, reaching a maximum value of 3.7 while exhibiting the minimum friction factor.

\section{References}

1. Bhuiya MMK, Chowdhury MSU, Saha M, Islam MT (2013) Heat transfer and friction factor characteristics in turbulent fl ow through a tube fitted with perforated twisted tape inserts. Int Commun Heat Mass Transf 46: 49-57.

2. Murugesan P, Mayilsamy K, Suresh S (2010) Heat transfer and friction factor studies in a circular tube fitted with twisted tape consisting of wire-nails. Chinese J Chem Eng 18(6): 1038-1042.

3. Eiamsa Ard S, Kongkaitpaiboon V, Nanan K (2013) Thermohydraulics of turbulent flow through heat exchanger tubes fitted with circular-rings and twisted tapes. Chinese J Chem Eng 21(6): 585-593.

4. Murugesan P, Mayilsamy K, Suresh S, Srinivasan PSS (2011) Heat transfer and pressure drop characteristics in a circular tube fitted with and without V-cut twisted tape insert. Int Commun Heat Mass Transf 38(3): 329-334.

5. Wongcharee K, Eiamsa-ard S (2011) Heat transfer enhancement by twisted tapes with alternate-axes and triangular, rectangular and trapezoidal wings. Chem Eng Process: Process Intensif 50(2): 211-219.

6. Skullong S, Promvonge P, Thianpong C, Jayranaiwachira N (2017) Thermal behaviors in a round tube equipped with quadruple perforateddelta-winglet pairs. Appl Therm Eng 115: 229-243.

7. Skullong S, Promvonge P, Thianpong C, Pimsarn M (2016) Heat transfer and turbulent flow friction in a round tube with staggered-winglet perforated-tapes. Int J Heat Mass Transf 95: 230-242.

8. Chingtuaythong W, Promvonge P, Thianpong C, Pimsarn M (2017) Heat transfer characterization in a tubular heat exchanger with V-shaped rings. Appl Therm Eng 110: 1164-1171.

9. Promvonge P, Tamna S, Pimsarn M, Thianpong C (2015) Thermal characterization in a circular tube fitted with inclined horseshoe baffles. Appl Therm Eng J 75: 1147-1155.

10. Bhuiya MMK, Ahamed JU, Chowdhury MSU, Sarkarc MAR, Salam B et al. (2012) Heat transfer enhancement and development of correlation for turbulent flow through a tube with triple helical tape inserts. Int Commun Heat Mass Transf 39(1): 94-101.

11. Gunes S, Ozceyhan V, Buyukalaca O (2010) Heat transfer enhancement in a tube with equilateral triangle cross sectioned coiled wire inserts. Exp Therm Fluid Sci 34(6): 684-691.

12. Webb RL (1981) Performance evaluation criteria for use of enhanced heat transfer surfaces in heat exchanger design. Int J Heat Mass Transf 24(4): 715-726
Creative Commons Attribution 4.0 International License

For possible submissions Click Here

\section{Submit Article}

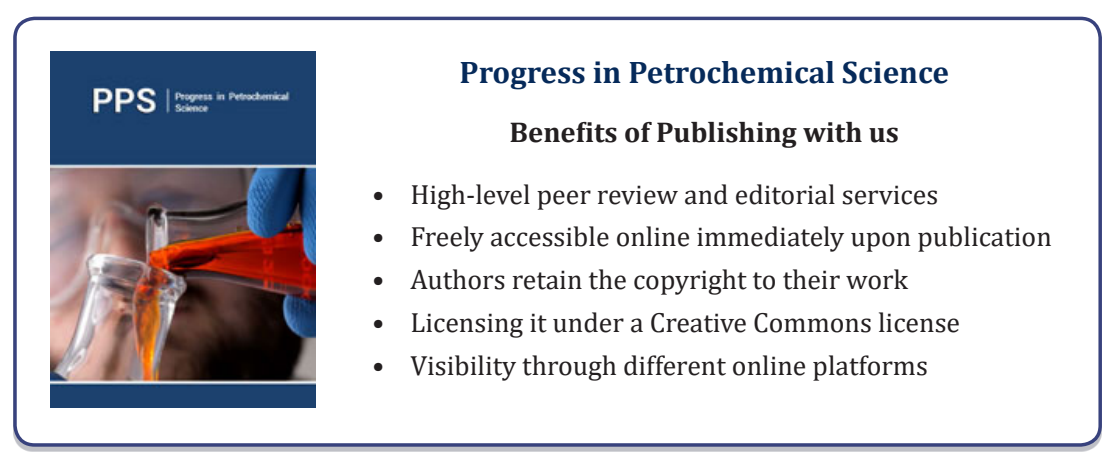

